\title{
Profesor Marian Kucała jako naukowiec, mistrz i nauczyciel
}

\author{
Professor Marian Kucata \\ as a Researcher, a Master and a Teacher
}

\begin{abstract}
ABSTRAKT
Artykuł jest skrótowym opisem dokonań naukowych i dydaktycznych prof. dra hab. Mariana Kucały (1927-2014), wybitnego ięzykoznawcy, mistrza i nauczyciela. Profesor Kucała jest autorem ponad 300 ksiqżek, artykułów i opracowań z zakresu dialektologii, historii języka polskiego, leksykografii historycznej i współczesnej, ięzyka religijnego, onomastyki, poprawności ięzykowej, współczesnego języka polskiego, a nawet glottodydaktyki. Był zasłużonym pracownikiem naukowym Instytutu Języka Polskiego PAN, nauczycielem akademickim, wychowawca wielu roczników polonistów Katolickiego Uniwersytetu Lubelskiego, popularyzatorem wiedzy o języku ojczystym. Wniósł ogromny wkład naukowy i organizacyiny w rozwói „Języka Polskiego”, jednego z najbardziej cenionych polskich czasopism jezzykoznawczych. Do najważniejszych prac Pana Profesora należq następujące publikacje zwarte: Porównawczy słownik trzech wsi małopolskich; Rozwói iłeratiwów dokonanych w ięzyku polskim; Rodzai gramatyczny w historii polszczyzny; Jakuba Parkosza traktat o ortografii polskiej; Twoja mowa cię zdradza. Regionalizmy i dialektyzmy iezzyka polskiego; Mały słownik poprawnei polszczyzny. W roku 2000 Instytut Języka Polskiego PAN wydał zbiór jego najważniejszych artykułów naukowych - Polszczyzna dawna i współczesna. Studia i szkice. Profesor Marian Kucała był współredaktorem Słownika staropolskiego
\end{abstract}

SPI Vol. 21, 2018/2

ISSN 2450-5358

e-ISSN 2450-5366

DOI: 10.12775/SPI.2018.2.004

Nadestano: 22.03.2018

Zaakceptowano: 17.05.2018

Artykuły i rozprawy 
oraz twórca koncepcii i redaktorem Słownika polszczyzny Jana Kochanowskiego. Jego prace naukowe z zakresu językoznawstwa diachronicznego i synchronicznego w najróżniejszych jego aspektach należq do głównego nurtu polskiego i słowiańskiego językoznawstwa. Profesor Marian Kucała prowadził wszechstronne badania językoznawcze, miał ogromnq wiedzę na temat funkcjonowania ięzyka polskiego w aspekcie diachronicznym i synchronicznym, cieszył się wielkim uznaniem w środowisku językoznawczym jako naukowiec i jako mistrz, promotor, nauczyciel, redaktor, który wywarł ogromny wpływ na rozwój naukowy wielu językoznawców w Polsce, udzielając im swojej wiedzy i patronując ich pracom naukowym.

\section{ABSTRACT}

The article shows the silhouette of prof. dr. hab. Marian Kucała (19272014), a great linguist, master and teacher. Professor is the author of about 300 books, articles, studies in the field of dialectology, history of Polish language, historical and contemporary lexicography, religious language, onomastics, linguistic correctness, contemporary Polish language and even glottodidactics. He was a distinguished scientist at the Institute of the Polish Language of the Polish Academy of Sciences, an academic teacher, teacher of many Polish students at the Catholic University of Lublin, popularizer of knowledge about native language, which should be described as a language teacher. He made a huge scientific and organizational contribution to the development of "Język Polski", one of the most valued Polish linguistics journals. The most important of his works are the following compact publications: Porównawczy słownik trzech wsi małopolskich; Rozwój iteratiwów dokonanych w ięzyku polskim; Rodzai gramatyczny w historii polszczyzny; Jakuba Parkosza traktat o ortografii polskiei; Twoja mowa cię zdradza. Regionalizmy i dialekłyzmy ięzyka polskiego; Mały słownik poprawnei polszczyzny. In 2000, the Institute of the Polish Language of the Pollish Academy of Science published a collection of his most important scientific articles: Polszczyzna dawna i współczesna. Studia i szkice. Professor Marian Kucała was the co-editor and editor of such significant lexicographical studies as the Stownik staropolski and the Słownik polszczyzny Jana Kochanowskiego. His scientific works representing diachronic and synchronous linguistics in a variety of aspects have had a significant impact on the development of Polish and Slavic linguistics. Professor Marian Kucała conducted a wide range of linguistic research, he had a great knowledge of how the Polish language functions in a diachronic and synchronous aspect, he enjoyed great recognition in the linguistic environment as a scientist and as a master, promoter, teacher who had a huge impact on the scientific development of many linguists in Poland, providing knowledge and promoting their scientific work. 
Profesor Marian Kucała (1927-2014) był naukowcem, który na trwale zapisał się w pamięci polskiego i słowiańskiego środowiska językoznawczego oraz swoich współpracowników, uczniów, studentów, słuchaczy, czytelników jako wielki uczony, jeden z najwybitniejszych współczesnych językoznawców polskich. Był zasłużonym pracownikiem naukowym Instytutu Języka Polskiego PAN, nauczycielem akademickim wielu roczników studentów polonistyki Katolickiego Uniwersytetu Lubelskiego, popularyzatorem wiedzy o języku ojczystym.

Urodził się we wsi Więciórka w powiecie myślenickim (obecnie znajdującej się w gminie Tokarnia) w chłopskiej rodzinie góralskiej, skąd wyniósł tradycyjne wartości pielęgnowane przez całe późniejsze życie - o czym czytamy w „Języku Polskim”: „Profesor Marian Kucała wywodzi się ze środowiska wiejskiego i uosabia jego najlepsze cechy: prawość, rzetelność w pracy i stosunkach z innymi, pracowitość”.

\section{Profesor Marian Kucała jako naukowiec}

Swoje życie rodzinne i zawodowe Profesor Kucała związał na stałe z Krakowem, tu ukończył Gimnazjum św. Jacka przy ulicy Siennej, a później, w latach 1948-1952, polonistykę ze specjalizacją językoznawstwo polskie na Uniwersytecie Jagiellońskim. Studiował pod okiem wybitnych profesorów, takich jak Kazimierz Nitsch, Witold Taszycki, Zenon Klemensiewicz, Stanisław Pigoń, którzy wpłynęli na ukształtowanie się jego drogi życiowej jako naukowca i dydaktyka. Szczególny wpływ wywarło na niego uczestnictwo w seminarium naukowym prof. Nitscha, który był twórcą polskiej dialektologii. Prof. Kucała znał doskonale gwarę góralską i pod kierunkiem tak znakomitego znawcy gwar polskich napisał pracę magisterską: Stownik gwary wsi Więciórka w pow. myślenickim w porównaniu ze stownikiem podbabiogórskiej Sidziny i nadwiślańskiego Facimiecha. Stopień doktora uzyskał w roku 1957 na podstawie rozprawy z zakresu leksykografii

1 "Język Polski” 1997, t. 77, s. 82. Por. też M. Malec, Profesor Marian Kucata (2 II 1927 - 20 X 2014), „Język Polski” 2015, t. 95, s. 202-206; E. Deptuchowa, Profesor Marian Kucata - historyk jezyka, leksykograf i dydaktyk, „LingVaria” 2016, t. 11, nr 1(21), s. 217-225; J. Reichan, Profesor M. Kucata jako dialektolog, „LingVaria” 2016, t. 11, nr 1(21), s. 227-237; P. Żmigrodzki, Profesor Marian Kucata - badacz i mitośnik języka polskiego, „LingVaria” 2016, t. 11, nr 1(21), s. 239-248. 
Porównawczy stownik trzech wsi matopolskich². Habilitację otrzymał na podstawie książki Rozwój iteratiwów dokonanych w jezzyku polskim (1966). W roku 1978 został profesorem nadzwyczajnym, a w 1984 uzyskał tytuł profesora zwyczajnego. Jego monografia pt. Rodzaj gramatyczny w historii polszczyzny, zawierająca kluczowe rozstrzygnięcia w podjętym temacie, zapewniła mu znaczące miejsce wśród najwybitniejszych polskich językoznawców. Prof. Kucała pracował w Zakładzie Językoznawstwa PAN w Krakowie w Pracowni Języka Staropolskiego i był współredaktorem monumentalnego Stownika staropolskiego od tomu pierwszego wydanego w roku 1953 do ostatniego, który ukazał się w roku 2002. Był także twórcą koncepcji i redaktorem Stownika polszczyzny Jana Kochanorwskiego wydawanego w IJP PAN w latach 1994-2012³. Wytężona, intensywna praca leksykograficzna, która wypełniła całe jego długie i owocne życie zawodowe, nie była przeszkodą w realizacji indywidualnych zamierzeń i planów naukowych. Przedmiotem badań naukowych Profesora był język rozumiany jako leksyka zróżnicowana stylistycznie oraz gramatyka z kategoriami fonetycznymi, morfologicznymi i składniowymi - narzędzie do porozumiewania się analizowane pod względem historycznym, geograficznym, społecznym. Dorobek naukowy pana Profesora Mariana Kucały liczy ponad 300 pozycji, wśród nich jest kilka książek, szereg artykułów, artykulików, studiów, szkiców,

2 Porównawczy stownik trzech wsi matopolskich jako słownik w ujęciu rzeczowym stał się inspiracją do stworzenia Stownika pojęciowego języka staropolskiego online (http://spjs.ijp.pan.pl). Por. też B. Sieradzka-Baziur, K. Kajtoch, Pojecie jezzyk w dwóch stownikach inspirowanych kategoryzacja semantycznq Rudolfa Halliga $i$ Walthera von Wartburga (Porównawczy stownik trzech wsi matopolskich i Stownik pojęciowy języka staropolskiego), w: Dawne z nowym tqczac... In memoriam Mariani Kucata, red. J. Klimek-Grądzka, M. Nowak, Lublin 2016, s. 101-118.

3 Por. B. Sieradzka-Baziur, Stownik polszczyzny Jana Kochanowskiego (opis), $\mathrm{w}$ : Stowniki dawne $i$ wspótczesne. Internetowy przewodnik edukacyjny, red. M. Bańko, M. Majdak, M. Czeszewski, Warszawa 2011, publikacja internetowa: www.leksykografia.uw.edu.pl [dostęp: 23.12.2011]; B. Sieradzka-Baziur, J. Duska, K. Kajtoch, Ukończony zostat Stownik polszczyzny Jana Kochanowskiego, „Język Polski” 2012, t. 92, nr 4, s. 241-248. Warto w tym miejscu podkreślić, że Profesor Marian Kucała sprawował pieczę nad całością tego przedsięwzięcia leksykograficznego od samego początku aż do momentu jego ukończenia. Był autorem koncepcji słownika i wnikliwym, wymagającym czytelnikiem wszystkich haseł opracowywanych przez członków zespołu - począwszy od etapu redagowania Stownika aż do ostatniej korekty. 
recenzji, omówień, dopisków do artykułów w „Języku Polskim”, głosów w dyskusji, które mieszczą się w obrębie takich zagadnień, jak dialektologia, historia języka polskiego, leksykografia historyczna i współczesna, język religijny ${ }^{4}$, onomastyka, poprawność językowa, współczesny język polski, a nawet glottodydaktyka5. Poważna część dorobku naukowego Profesora dotyczy zagadnień dialektologicznych, o czym świadczą wspomniane już prace: magisterska i doktorska, a także popularnonaukowa książka Troja mowa cię zdradza. Regionalizmy i dialektyzmy jezzyka polskiego $(1994,2002)^{6}$ oraz często przytaczany i wciąż aktualny - uznawany za prekursorski w badaniach integracji gwar i języka ogólnego - artykuł O stownictwie ludzi wyzbywających się grwary (1960), w podsumowaniu którego autor posługując się właściwym dla siebie, jasnym i zrozumiałym językiem stwierdza:

Stwierdziliśmy wyżej na przykładach, że omawiani tu ludzie zatracają mnóstwo pojęć językowi literackiemu nieznanych wraz z zatracaniem wyrazów za bardzo "gwarowo" brzmiących, stwierdziliśmy dalej, że ginie wiele wyrazów gwarowych i pojęć zastępowanych przez bardziej literackie wyrazy bliskoznaczne [...], co doprowadza często do tego, że niektóre liczne gwarowe grupy wyrazów bliskoznacznych zastępuje się nielicznymi ogólnymi terminami, dalej zauważyliśmy unikanie pewnej ilości słów istniejących i w języku literackim, mylnie uważanych za wyłącznie gwarowe, w końcu, że spośród wyrazów mających w literackim inne odpowiedniki również pewna częśc $\mathrm{w}$ tym słownictwie nie występuje. To po stronie minusów. Po stronie plusów dość duża ilość literackich wyrazów, z których tylko część określa nowe, gwarze nieznane

$4 \quad \mathrm{Na}$ szczególną uwagę zasługują trzy teksty Profesora na temat nazywania istot duchowych w polszczyźnie: M. Kucała, Nazywanie Boga Ojca w historii polszczyzny, w: Obraz Boga Ojca w kulturze, red. M. Ołdakowska-Kuflowa, U.M. Mazurczak, Lublin 2000, s. 55-66; M. Kucała, Nazywanie Chrystusa w historii polszczyzny, w: Tysiqc lat polskiego stownictwa religijnego, red. B. Kreja, Gdańsk 1999, s. 205-212; M. Kucała, Od „Bogurodzicy” do „Madonny". Nazywanie Matki Boskiej w historii polszczyzny, w: O jezzyku religijnym. Zagadnienia wybrane, red. M. Karpluk, J. Sambor, Lublin 1988, s. 133-144.

5 Pełna bibliografia prac prof. Mariana Kucały, opracowana przez Zygmunta Gałeckiego z okazji nadania Profesorowi tytułu doktora honoris causa KUL w roku 2012, liczy 331 pozycji. Por. Profesor Marian Kucata, doktor honoris causa Katolickiego Uniwersytetu Lubelskiego Jana Pawta II, Lublin 27 czerwca 2012 r., s. 67-91.

6 Tytuł jest kreatywnym wykorzystaniem słów, które zostały skierowane do św. Piotra przez tłum w czasie przesłuchania Jezusa przez Sanhedryn (Mt 26,73). 
pojęcia. Bilans niewesoły. Widać jasno, że jeśli idzie o pojęcia, o wiele więcej ludzie ci tracą z gwary, niż przejmują z języka literackiego. A na czymże polega prawdziwe bogactwo języka? Chyba przede wszystkim na możliwości jak najdokładniejszego wyrażenia jak największej ilości pojęć. Jeżeli tak, to język ludzi wyzbywających się gwary, tutaj omówiony, jest bardzo ubogi ${ }^{7}$.

Profesor Marian Kucała to także wybitny historyk języka, o czym świadczą artykuły hasłowe w Stowniku staropolskim, redagowanie Stownika polszczyzny Jana Kochanowskiego, rozprawa habilitacyjna Rozwój iteratywów dokonanych w języku polskim (1966), monografia profesorska Rodzaj gramatyczny w historii polszczyzny (1978). Pozycję prof. Kucały jako wybitnego historyka języka ugruntowało krytyczne wydanie Traktatu o ortografii polskiej Jakuba Parkosza (1985), redakcja pracy zbiorowej O jezzyku poetyckim Jana Kochanowskiego (1984) oraz liczne ważne artykuły z zakresu historii języka, opublikowane w najbardziej poczytnych czasopismach naukowych. Dotyczyły one zagadnień historycznej ortografii, składni, fleksji, fonetyki, rymów, semantyki itp. Na uwagę zasługuje artykuł, w którym autor uzasadnia potrzebę studiowania przedmiotów z zakresu historii języka, o czym w obecnej uniwersyteckiej dydaktyce polonistycznej się, niestety, zapomina ${ }^{8}$. W jego dorobku naukowym są też prace onomastyczne, m.in. na temat statusu nazw własnych oraz etymologii nazw miejscowych.

Prof. Kucała był aktywnym uczestnikiem życia naukowego w Polsce - polonistycznego i slawistycznego. Uczestniczył w licznych konferencjach, zjazdach, sesjach, występując jako referent i uważny dyskutant. Był członkiem Polskiej Akademii Umiejętności i wielu naukowych towarzystw i gremiów, m.in. Towarzystwa Naukowego KUL, Lubelskiego Towarzystwa Naukowego, Komisji Dialektologicznej Komitetu Językoznawstwa PAN, Rady Języka Polskiego, Towarzystwa Miłośników Języka Polskiego oraz Polskiego Towarzystwa Językoznawczego.

7 M. Kucała, O stownictwie ludzi wyzbywajacych sie grwary, „Biuletyn PTJ” 1960, t. 19, s. 141-154, 155-156.

8 M. Kucała, Wskazywanie praktycznej przydatności wiedzy historycznojezykowej, w: Synchronia - diachronia. Materiaty z konferencji "Problematyka historycznojezzykowa we wspótczesnym językoznawstwie i jej miejsce w dydaktyce”. Wyższa Szkota Pedagogiczna im. Jana Kochanowskiego, Kielce 17-18 listopada 1997, red. M. Wojtyła-Świerzowska, Kielce 1999, s. 81-87. 


\section{Profesor Marian Kucała jako pedagog i dydaktyk}

Marian Kucała przez całe swoje zawodowe życie zajmował się także pedagogiką językową, czyniąc rozliczne starania o czystość językową polszczyzny. Profesor stał na stanowisku, że obowiązkiem językoznawcy-polonisty jest troska o poprawność i piękno języka polskiego. Już w czasach studenckich nawiązał kontakt z Towarzystwem Miłośników Języka Polskiego i jego organem „Językiem Polskim", którego redaktorem był w tym czasie Kazimierz Nitsch. Od roku 1972 był członkiem zespołu redakcyjnego tego jednego z najważniejszych polskich czasopism językoznawczych, w latach 19781986 pełnił w nim funkcję sekretarza naukowego, a następnie, w latach 1998-2004, redaktora naczelnego. Przez dziesiątki lat swojego pracowitego życia czytał i korygował nadsyłane do redakcji teksty, korespondował $\mathrm{z}$ ich autorami, negocjując ostateczny kształt kierowanych do druku tekstów. $\mathrm{Na}$ łamach czasopisma odpowiadał też na pytania czytelników dotyczące spraw poprawnościowych, a także pisał własne artykuły na temat kultury języka polskiego. Artykuły te i odpowiedzi czytelnikom adresowane byly przede wszystkim do nauczycieli. Język tych publikacji jest prosty i zrozumiały - prof. $\mathrm{Ku}-$ cała potrafił przy użyciu takiego właśnie przystępnego języka jasno i przejrzyście przedstawić trudne i skomplikowane niejednokrotnie zagadnienia, było to charakterystyczną cechą jego stylu pisania. W artykułach i innych tekstach zamieszczanych w „Języku Polskim” uwidacznia się talent pedagogiczny Profesora, który chciał i umiał się dzielić swoją wiedzą z czytelnikami. Piotr Żmigrodzki pisze:

W KUL-owskiej bibliografii prac profesora (Gałecki 2012) naliczyłem 191 pozycji odnoszących się do publikacji w „Języku Polskim”, a więc blisko 58\% całego dorobku. Reprezentują one najróżniejsze gatunki i formy tekstów. Najwięcej jest notatek w dziale Odpowiedzi redakcji, bo aż 67 (pisał je jeszcze wtedy, gdy formalnie członkiem redakcji nie był), 34 pozycje to dopiski do artykułów innych autorów, 29 - recenzje publikacji językoznawczych, 11 - sprawozdania z konferencji naukowych, 7 teksty okolicznościowe, wspomnienia, nekrologi, 5 - polemiki z innymi artykułami drukowanymi w JP. Są oczywiście też i artykuły poważniejsze; ogólna statystyka pozwala wszak określić ten dorobek jako typowy dla członka redakcji, któremu powierza się nieraz trudne i niewdzięczne zadania - bo przecież odpowiedzi na pytania czytelników nieraz wymagają ogromnego przygotowania, lektury słowników, poszukiwań bibliograficznych, efektem zaś bywa krótki artykulik, na który po latach mało 
kto zwraca uwagę. Niewątpliwie ta działalność prof. Kucały mieści się w kategoriach jego służby sprawie pedagogiki językowej, popularyzacji wiedzy o języku?.

Ukoronowaniem prac z zakresu pedagogiki językowej stał się Maty stownik poprawnej polszczyzny, wydany przez Towarzystwo Miłośników Języka Polskiego w roku 1995 i ponownie, w wersji rozszerzonej, w roku 1999. Obejmuje on opis funkcjonowania około 7 tys. jednostek hasłowych, które mogą wywołać wątpliwości poprawnościowe u użytkowników języka polskiego.

\section{Profesor Marian Kucała a jego uczniowie}

Prof. Marian Kucała wychował uczniów, którzy pod jego kierunkiem zdobyli wiedzę i umiejętności w zakresie językoznawstwa. Wypromował siedmiu doktorów - w Krakowie, w Instytucie Języka Polskiego PAN Felicję Wysocką, Ewę Deptuchową, Ireneusza Bobrowskiego, Macieja Kawkę, Lidię Trześniowską, Bożenę Sieradzką-Baziur, i w Lublinie na Katolickim Uniwersytecie Lubelskim Zygmunta Gałeckiego i Beatę Kułak.

\section{Profesor Marian Kucała a jego studenci}

Na uwagę zasługuje też działalność dydaktyczna Pana Profesora. Będąc pracownikiem Instytutu Języka Polskiego PAN, nie prowadził zajęć dydaktycznych. W roku 1974 rozpoczął pracę dodatkową w Katedrze Języka Polskiego KUL, dokąd dojeżdżał do 1997 roku i gdzie wykształcił około 60 magistrów, promując prace z zakresu dialektologii, onomastyki, językoznawstwa współczesnego i historycznego. Katolicki Uniwersytet Lubelski w uznaniu zasług przyznał mu uchwałą Senatu z dnia 26 kwietnia 2012 roku doktorat honoris causa. Przez kilka lat (od 1998 r.) Profesor pracował także w Wyższej Szkole Humanistyczno-Ekonomicznej w Łodzi (później Akademii Humanistyczno-Ekonomicznej), gdzie prowadził dla studentów zajęcia z zakresu języka współczesnego oraz historii języka polskiego

9 P. Żmigrodzki, Profesor Marian Kucata - badacz i mitośnik języka polskiego, „LingVaria” 2016, t. 11, nr 1(21), s. 244. 
i dialektologii. Do dokonań z zakresu dydaktyki należy włączyć publikację Profesora: The History of Polish Language (1979) i jej zmienione wydanie Language z 1984 roku. Jest to zarys historii języka polskiego dla cudzoziemców, wykorzystywany jako pomoc dydaktyczna $\mathrm{w}$ procesie nauczania języka polskiego jako obcego.

\section{Osobista refleksja}

Profesor Marian Kucała był promotorem mojej rozprawy doktorskiej dotyczącej języka Jana Kochanowskiego oraz recenzentem monografii habilitacyjnej na temat języka Jana Kasprowicza. Uważam Go za swojego mistrza i nauczyciela, i jest dla mnie wielkim zaszczytem zaliczać się do grona Jego uczniów. Kiedy myślę o Nim, moja pamięć przywołuje przede wszystkim początki mojej pracy w Instytucie Języka Polskiego PAN w roku 1989, pamiętnym roku demokratycznych przemian w naszym kraju. Po zakończeniu studiów w ówczesnej Wyższej Szkole Pedagogicznej w Krakowie zostałam zatrudniona w zespole redagującym Stownik polszczyzny Jana Kochanowskiego, w którym pracowali wytrawni leksykografowie. Zadaniem, które przydzielił mi Profesor, było redagowanie haseł słownikowych - choć spodziewałam się, że na początek otrzymam jakieś pośledniejsze zadanie korektorskie. Bardzo to doceniałam, starałam się nie zawieść zaufania Pana Profesora, zgłębiając zasady pracy leksykograficznej pod jego czujnym, krytycznym, lecz sprawiedliwym okiem. Przystąpiwszy do własnej pracy naukowej, przedstawiałam Profesorowi do korekty swoje artykuły, prosząc o uwagi. Profesor nigdy nie odmawiał, teksty czytał bardzo wnikliwie i obszernie je komentował, poświęcając rozmowie na ich temat dużo czasu. Jestem bardzo wdzięczna Panu Profesorowi za poświęcony mi drogocenny czas, który mógł spożytkować na pisanie swoich własnych rozpraw naukowych. Na opiekę mistrza zawsze można było liczyć. Profesor nigdy nie odmawiał lektury tekstów różnym autorom, poświęcał tej pracy bardzo wiele czasu, a jego uwagi były zawsze niezwykle pomocne i traktowane z ogromnym szacunkiem, bo Profesor był wybitnym specjalistą i mieliśmy zawsze pełną tego świadomość. I inne wspomnienie, które pielęgnuję z wdzięcznością, jako szczególnie dla siebie ważne. Otóż w 2002 roku wyjeżdżałam z małym synem (miał wtedy cztery i pół roku) na dwa lata do Japonii, gdzie miałam podjąć 
zatrudnienie w Tokyo University of Foreign Studies jako visiting professor. Ostatniego dnia pracy w Instytucie Języka Polskiego Polskiej Akademii Nauk Pan Profesor zauważył chyba mój niewyrażony werbalnie niepokój, lęk przed nieznanym i zapewne obawy co do przyszłego zatrudnienia po powrocie. Wypowiedział wtedy proste, lecz jakże ważne dla mnie zdanie, które było moim umocnieniem przez długi czas pobytu za granicą: „To biurko będzie na Panią czekało". I tak było istotnie.

My, Jego uczniowie, zapamiętaliśmy Pana Profesora Mariana Kucałę jako człowieka prawego i szlachetnego, który wymagał bardzo dużo od siebie - wysokie wymagania stawiał też innym. Jego postawa była głęboko religijna, wierzył w Pana Boga i postępował zgodnie ze swoimi zasadami, którym zawsze pozostawał wierny.

\section{Podsumowanie}

Profesor Marian Kucała prowadził badania językoznawcze o szerokim zakresie, miał ogromną wiedzę na temat funkcjonowania języka polskiego w aspekcie diachronicznym i synchronicznym, cieszył się wielkim uznaniem w środowisku językoznawczym jako naukowiec i jako mistrz, promotor, nauczyciel. Był człowiekiem, który wywarł ogromny wpływ na rozwój naukowy wielu językoznawców w Polsce, udzielając im swojej wiedzy i promując ich prace naukowe. Jakie określenia rzeczownikowe charakteryzują go najtrafniej? Spośród licznych terminów pedagogicznych, które są wyznacznikami leksykalnymi pojęcia NAUCZYCIEL określenia pasujące najbardziej do prof. M. Kucały to: profesor, naukowiec, badacz, uczony, pracownik nauki, pracownik naukowy; nauczyciel, nauczyciel akademicki, wyktadowca, egzaminator, nauczyciel-pedagog, pedagog, pedagog jezyka; mistrz, mentor, autorytet moralny, autorytet intelektualny, autorytet religijny.

\section{Bibliografia}

Deptuchowa E., Profesor Marian Kucata - bistorykjęzyka, leksykografi dydaktyk, „Ling:Varia” 2016, t. 11, nr 1(21), s. 217-225.

Gałecki Z., Profesor Marian Kucata, doktor honoris causa Katolickiego Uniwersytetu Lubelskiego Jana Pawta II, Lublin 27 czerwca 2012 r.

Kucała M., Porównawczy stownik trzech wsi matopolskich, (Prace Językoznawcze PAN, t. 11), Zakład Narodowy im. Ossolińskich, Wrocław 1957. 
Kucała M., O stownictwie ludzi wyzbywajacych sie grwary, „Biuletyn PTJ” 1960, t. 19, s. 141-154.

Kucała M., Rozwój iteratiwów dokonanych w języku polskim, (Prace Komisji Językoznawstwa PAN, t. 8), Zakład Narodowy im. Ossolińskich, Wroclaw 1966.

Kucała M., Rodzaj gramatyczny w historii polszczyzny, (Prace IJP PAN, t. 23), Zakład Narodowy im. Ossolińskich, Wrocław 1978.

Kucała M., The History of Polish Language, w: An Outline of the History of Polish Culture, red. B. Klimaszewski, Wydawnictwo Uniwersytetu Jagiellońskiego, Kraków 1979, s. 41-45, 78-81, 113-115, 147-148, 176-177, 204-205, 239-241, 272, 302-303, 327-329, 373-374.

Kucała M., Language, w: An Outline History of Polish Culture, Wydawnictwo Interpress, Warszawa 1984, s. 41-44, 75-78, 103-105, 140-141, 167-168, 200-201, 221-222, 256-257, 289, 306-308.

Kucała M.,Jakuba Parkosza traktat o ortografii polskiej, PWN, Warszawa 1985.

Kucała M., Od „Bogurodzicy” do „Madonny”. Nazywanie Matki Boskiej w historii polszczyzny, w: O języku religijnym. Zagadnienia wybrane, red. M. Karpluk, J. Sambor, Redakcja Wydawnictw KUL, Lublin 1988, s. $133-144$.

Kucała M., Twoja mowa cię zdradza. Regionalizmy i dialektyzmy jezzyka polskiego, Towarzystwo Miłośników Języka Polskiego, Kraków 1994.

Kucała M., Maty stownik poprawnej polszczyzny, Towarzystwo Miłośników Języka Polskiego, Kraków - Warszawa 1995.

Kucała M., Wskazywanie praktycznej przydatności wiedzy historycznojezykowej, w: Synchronia - diachronia. Materiaty z konferencji „Problematyka historycznojęzykowa we wspótczesnym językoznawstwie i jej miejsce w dydaktyce". Wyższa Szkota Pedagogiczna im. Jana Kochanowskiego, Kielce 1718 listopada 1997, red. M. Wojtyła-Świerzowska, Wydawnictwo WSP, Kielce 1999, s. 81-87.

Kucała M., Nazywanie Chrystusa w historii polszczyzny, w: Tysiac lat polskiego stownictwa religijnego, red. B. Kreja, Wydawnictwo Uniwersytetu Gdańskiego, Gdańsk 1999, s. 205-212.

Kucała M., Nazywanie Boga Ojca w historii polszczyzny, w: Obraz Boga Ojca w kulturze, red. M. Ołdakowska-Kuflowa, U.M. Mazurczak, Redakcja Wydawnictw KUL, Lublin 2000, s. 55-66.

Kucała M., Polszczyzna dawna i wspótczesna. Studia i szkice, Instytut Języka Polskiego PAN, Kraków 2000.

Profesor Marian Kucata, Doktor Honoris Causa Katolickiego Uniwersytetu Lubelskiego Jana Pawta II, Lublin 27 czerwca 2012 r., publikacja w serii „Doktorzy Honoris Causa”, nr 10, KUL, Lublin 2012.

Reichan J., Profesor M. Kucata jako dialektolog, „LingVaria” 2016, t. 11, nr 1(21), s. 227-237.

Sieradzka-Baziur B., Stownik polszczyzny Jana Kochanowskiego (opis), w: Stowniki dawne $i$ wspótczesne. Internetowy przewodnik edukacyjny, red. 
M. Bańko, M. Majdak, M. Czeszewski, Warszawskie Koło Leksykograficzne, 2011, publikacja internetowa: www.leksykografia.uw.edu.pl [dostęp: 23.12.2011]

Sieradzka-Baziur B., Duska J., Kajtoch K., Ukończony zostat Stownik polszczyzny Jana Kochanowskiego, ,Język Polski” 2012, t. 92, nr 4, s. 241-248.

Sieradzka-Baziur B., Kajtoch K., Pojęcie jezyk w dwóch stownikach inspirowanych kategoryzacja semantyczna Rudolfa Halliga i Walthera von Wartburga (Porównawczy stownik trzech wsi matopolskich i Stownik pojeciowy jezyka staropolskiego), w: Dawne z nowym taczac... In memoriam Mariani Kucata, red. J. Klimek-Grądzka, M. Nowak, Towarzystwo Naukowe KUL, Lublin 2016, s. 101-118.

Stownik pojeciowy jezzyka staropolskiego online, 2015, kierownik projektu B. Sieradzka-Baziur, http://spjs.ijp.pan.pl.

Stownik polszczyzny Jana Kochanowskiego, t. 1-5, red. M. Kucała, Instytut Języka Polskiego PAN, Kraków 1994-2012.

Stownik staropolski, red. S. Urbańczyk, t. 1-11, Instytut Języka Polskiego PAN, Kraków 1953-2002.

Żmigrodzki P., Profesor Marian Kucata - badacz i mitośnik jezyka polskiego, „LingVaria” 2016, t. 11, nr 1(21), s. 239-248.

\section{ADRES DO KORESPONDENCJI:}

Dr hab. Bożena Sieradzka-Baziur, prof. AIK

Akademia Ignatianum w Krakowie

Wydział Pedagogiczny

e-mail: sieradzka4@gmail.com 